\title{
THE INVESTIGATION OF MEDICAL STUDENT JOURNALS
}

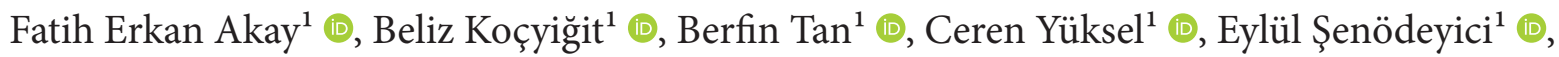 \\ Elif Çalışkan ${ }^{1} \odot$, Janset Özdemir ${ }^{1} \odot$, Pınar Tuncer ${ }^{1} \odot$, Necdet Süt ${ }^{2}$ (1)
}

${ }^{1}$ Trakya University School of Medicine, Edirne, TURKEY

${ }^{2}$ Department of Biostatistics and Informatics, Trakya University School of Medicine, Edirne, TURKEY

\begin{abstract}
Aims: The aim of our study is to examine and evaluate data of medical student journals from around the world for the year 2020. Methods: In this observational study 20 medical student journals were examined. Data analyzed comprised of the year of foundation, country of origin, number of issues per year, types of articles published, and the total number of articles published in a year. Issues that were published in 2020 only were taken into consideration. Results: In 2020, the majority of medical student journals were based in the United States of America, followed by Canada. There were only four indexed (Scopus, Science Citation Index Expanded, PubMed) medical student journals; three were from the United States of America, and one from Canada. In comparison with other journals, the Yale Journal of Biology and Medicine had the most published issues. They also have the most crowded editorial board. Overall, the median of people on the editorial boards and advisory boards were 17.5 and 14, respectively. The median for issues per year was 2 . The median number of publications in medical student journals in 2020 was 23 . Among them, $13.1 \%$ were original research articles, $10.8 \%$ review articles, $9.4 \%$ case reports, $4.9 \%$ editorials, and $2.9 \%$ letters to the editor. The remaining 59.0\% were publications that fell into the "others" category. Conclusion: In conclusion, the majority of medical student journals are based in North America and Europe, and a substantial amount of the published articles falls into the "others" category. Considering the lack of effective guidance and regulations with relevance to indexing. Medical student journals face certain challenges regarding visibility, accessibility, and publishing articles. However, provided that the editors of medical student journals remain keen, motivated, and focused, medical student journals will contribute to the scientific community by creating a supportive and intellectual environment for aspiring researchers where they can enhance their understanding of scientific research and publishing skills. Keywords: Medical students, medical student journal, publications
\end{abstract}

\section{INTRODUCTION}

Medical students played a significant role throughout the development of basic and clinical sciences in history. In recent years, there has been an increase in schools encouraging their students to carry out scientific research, which sets a prerequisite for their graduation (1). Students may attain knowledge about critical reading and evidence-based medicine through these compulsory and voluntary studies $(2,3)$.

Medical student journals (MSJs) are establishments arising from the desire of medical students to create platforms for other students to share their articles and findings (3). MSJs can also set examples by encouraging students to conduct and publish scientific research themselves. Therefore, student journals are seen as a unifying element between young researchers and the scientific world.

There are MSJs reported from all around the world. Some are run and published by editorial boards that exclusively consist of medical students $(2,4)$. The scope and the working principles of these journals vary within each other. While some of them publish only articles related to health and medicine, some have hybrid content where art and culture-related articles are published as well. Their primary purpose is the dissemination of knowledge gained through scholarly work. Another contribution of MSJs is to close the gap between clinical and experimental studies in the publication field (5).
Medical student journals' role and possible effect are often discussed as being prime examples of medical students' interests in research or developing research abilities $(6,7)$. The first issue of a medical student journal (MSJ) was published in 1923 (2). Since then, the number of journals has been increasing over the past years, and the best-observed leap has been in the last fifteen years (2). Although most of these journals are not indexed in MEDLINE, the peer-review process conducted by students is as stringent as any peer-review carried out by faculty members $(4,8)$.

A recent study described that students who publish works in MSJs during their undergraduate years are more likely to succeed in their future careers (7). Moreover, graduating medical students will enroll in future research activities with a more meticulous demeanor if guided properly by adequate role models during their undergraduate studies (9). MSJs could provide the necessary motivation and guidance to undergraduate students by being a stepping stone to the field of publication and research. The aim of this study is to examine MSJs from the year 2020 around the world.

\section{MATERIAL AND METHODS}

In this observational study, the data collection was made by searching the term "medical student journal" on search engines like Google@ (www.google.com), Yahoo! (www.yahoo.com), and Bing (www.bing.com), and on bibliometric databases such as 
Web of Science, PubMed, and Scopus. The term "medical student journal" refers to journals that publish actively and periodically, whose editorial boards consist mostly or exclusively of medical students. 23 medical student journals were included after this initial data screening. Due to lack of data, 3 of them were attempted to be contacted via email but no response was received. They were excluded from the study due to insufficient data.

Data used for the classification of the journals were the year of foundation, country of origin, number of issues per year, types of articles published, number of articles per issue, and the total number of articles published in a year. Issues that were published only in 2020 were taken into consideration while analyzing the types and numbers of articles. Data concerning the editorial board included the number of editors in the board and the number of professors in the editorial advisory board.

Percentages, mean and standard deviation were used as the descriptive statistics. The number of issues per year, the number of people on the editorial board, the number of people on the editorial advisory board, publication in 2020, and the total number of publications in 2020 were presented as mean, standard deviation, minimum and maximum, median and interquartile range. Distribution of publications in journals by article types and the overall number of articles published in journals are presented as numbers and percentages. Along with the general characteristics of journals, issue per journal, the number of people in the editorial board, the number of people in the editorial advisory board, and the total number of publications in 2020 were also presented as percentages. A p-value $<0.05$ was set for statistical significance. The data were analyzed with IBM SPSS version 23.0.

\section{RESULTS}

In this study, twenty MSJs were evaluated based on their publications in the year 2020. Our study shows an increase in MSJs considering there were only four in the 1900s, three of them being in Canada and one in the United States of America (USA). Therefore, the number of MSJs considerably increased in the 2000s (Figure 1)

The summary of journals' characteristics (years of foundation, country, indexes, issues per year, number of people on the editorial and editorial advisory board) are presented in Table 1 . The majority of MSJs were from the USA, followed by Canada. Overall, $80 \%$ of journals were from North America and Europe. There were only six MSJs indexed in medical indexes, four were from the USA, and the other two were from Canada and Turkey. $70 \%$ of the journals were not indexed. In comparison with other journals, the Yale Journal of Biology and Medicine had the most published issues in the year 2020. They also had the most crowded editorial board.

Overall, the median number of people on the editorial and editorial advisory boards were 14 and 18.3, respectively. The median number of yearly publications was 2 issues, with most of the journals publishing 2 issues per year. Table 2 shows statistics of the journals' issues per year, the number of people on the editorial board, the number of people on the editorial advisory board, and the total number of publications in 2020.

Table 3 shows the number of journals' publications and publication type's percentage distributions in 2020, with the International Journal of Medical Students having the most publications (82 publications). With just 5 publications per year, American Medical Student Research Journal published the fewest. The type of publications published by the journals varied according to their "aims and scope". The median number of publications in MSJs in 2020 was 23 . Among them, $13.1 \%$ were original research articles, $10.8 \%$ review articles, $9.4 \%$ case reports, $4.9 \%$ editorials, and $2.9 \%$ letters to the editor. The remaining $59.0 \%$ were publications that fell into the "others" category. The "others" category comprised of interviews, approaches to patient perspective, fine arts, reflections, short communications, news, symposium pieces, clinical images, book reviews, profiles, clinical reports, solving statics, teachable moments, ethics challenge, feature articles, research spotlights, clinical practices, staff reviews, abstracts, emerging trends, focuses on medical humanities, research news, technical reports, creative writing pieces, quizzes, discussion starters, sound pieces, education reflections, visual pieces (digital effects), poetry, viewpoint, images in medicine, picture quizzes, study resources, and eye spy. Medical Student Research Journal was excluded from this table due to inadequate information.

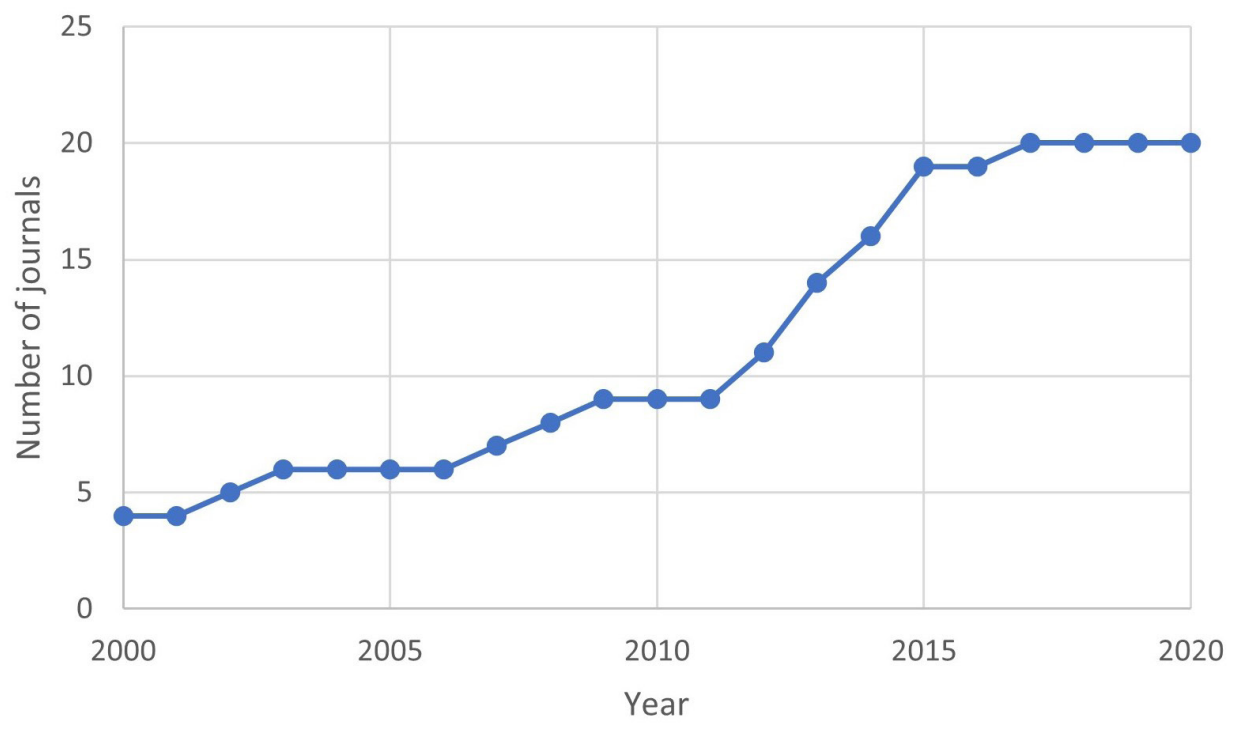

Figure 1: Number of journals in the last 20 years. 
Table 1: Summary of journals' general characteristics.

\begin{tabular}{|c|c|c|c|c|c|c|}
\hline Name & $\begin{array}{c}\text { Year of } \\
\text { foundation }\end{array}$ & Country & Indexed in & $\begin{array}{l}\text { Issue } \\
\text { per year } \\
(n)\end{array}$ & $\begin{array}{l}\text { People on the } \\
\text { editorial board } \\
\text { (n) }\end{array}$ & $\begin{array}{c}\text { People on the editorial } \\
\text { advisory board } \\
(n)\end{array}$ \\
\hline University of Toronto Medical Journal & 1923 & Canada & Scopus & 3 & 49 & 10 \\
\hline Yale Journal of Biology and Medicine & 1928 & USA & Scopus / SCIE & 5 & 78 & 15 \\
\hline Dalhousie Medical Journal & 1936 & Canada & N/A & 2 & 15 & N/A \\
\hline $\begin{array}{l}\text { University of British Columbia Medical } \\
\text { Journal }\end{array}$ & 1962 & Canada & N/A & 2 & N/A & N/A \\
\hline New Zealand Medical Student Journal & 2002 & New Zealand & N/A & 2 & 15 & 5 \\
\hline McMaster University Medical Journal & 2003 & Canada & N/A & 1 & 13 & N/A \\
\hline Medical Student Research Journal & 2007 & USA & N/A & 3 & 20 & 1 \\
\hline $\begin{array}{l}\text { Royal College of Surgeons in Ireland } \\
\text { Student Medicine Journal }\end{array}$ & 2008 & Ireland & N/A & 1 & N/A & N/A \\
\hline Australian Medical Student Journal & 2009 & Australia & N/A & 2 & 30 & 22 \\
\hline $\begin{array}{l}\text { University College Dublin Medical } \\
\text { Student Journal }\end{array}$ & 2012 & Ireland & N/A & 1 & 10 & N/A \\
\hline $\begin{array}{l}\text { Journal of Asian Medical Students } \\
\text { Association }\end{array}$ & 2012 & $\begin{array}{l}\text { Asian-Pacific } \\
\text { Region }\end{array}$ & N/A & 2 & 14 & 3 \\
\hline Medical Student Press Journal & 2013 & USA & N/A & 2 & 10 & 2 \\
\hline $\begin{array}{l}\text { International Journal of Medical } \\
\text { Students }\end{array}$ & 2013 & USA & $\begin{array}{l}\text { BASE / Bibliotheca Alexandrina } \\
\text { Information for Africa / DOAJ / EZB / } \\
\text { HINARI / ICMJE / IMBIOMED / J Gate / } \\
\text { Journal Guide / Journal Seek Database / } \\
\text { OCLC WorldCat / Publons / Pubshub / } \\
\text { Research Bible / The Open Access Digital } \\
\text { Library / Ulrich's International Periodical } \\
\text { Directory / Summon by Serial Solutions }\end{array}$ & 3 & 63 & N/A \\
\hline $\begin{array}{l}\text { American Medical Student Research } \\
\text { Journal }\end{array}$ & 2013 & USA & N/A & 1 & 12 & 38 \\
\hline Turkish Medical Student Journal & 2014 & Turkey & $\begin{array}{l}\text { CABI: CAB Abstracts and Global Health / } \\
\text { Türk Medline / Scilit }\end{array}$ & 3 & 28 & 50 \\
\hline Harvard Medical Student Journal & 2014 & USA & PubMed & 1 & 33 & 14 \\
\hline The McGill Journal of Medicine & 2015 & Canada & N/A & 2 & 52 & N/A \\
\hline Amsterdam Medical Student Journal & 2015 & Netherlands & N/A & 4 & 13 & 54 \\
\hline Florida Medical Student Review Journal & 2015 & USA & PubMed & 1 & 20 & 18 \\
\hline British Student Doctor Journal & 2017 & UK & N/A & 3 & 14 & 6 \\
\hline
\end{tabular}

N/A: Not available, USA: United States of America, UK: United Kingdom, BASE: Bielefeld Academic Search Engine, CAB: Center for Agriculture and Bioscience, CABI: Center for Agriculture and Bioscience International, DOAJ: Directory of Open Access Journals, EZB: Elektronische Zeitschriftenbibliothek, HINARI: Health InterNetwork, ICMJE: List of Publications that follow the International Committee of Medical Journal Editors, IMBIOMED: Mexican Index of Latin American Biomedical Journals, J Gate: The e-Journal Gateway, OCLC: Online Computer Library Center, SCIE: Science Citation Index Expanded

Table 2: Descriptive statistics of the journals.

\section{Descriptive Statistics}

\begin{tabular}{lcc} 
& Mean \pm SD (min-max) & Median (IQR) \\
\hline Issues per year & $2.2 \pm 1.1(1-5)$ & $2(2)$ \\
People on the editorial board & $27.2 \pm 20.2(10-78)$ & $17.5(24)$ \\
People on the editorial advisory board & $18.3 \pm 18.0(1-54)$ & $14(26)$ \\
Total number of publications in 2020 & $29.5 \pm 23.0(5-82)$ & $23(30)$ \\
\hline
\end{tabular}


Table 3: The number of articles published in journals and their percentage distribution by type.

\begin{tabular}{|c|c|c|c|c|c|c|c|}
\hline Name & $\begin{array}{l}\text { Total number of } \\
\text { publications in } \\
\quad 2020(n)\end{array}$ & $\begin{array}{l}\text { Original research } \\
\text { article (\%) }\end{array}$ & $\begin{array}{c}\text { Review } \\
\text { article (\%) }\end{array}$ & $\begin{array}{c}\text { Case report } \\
(\%)\end{array}$ & $\begin{array}{l}\text { Editorial } \\
(\%)\end{array}$ & $\begin{array}{l}\text { Letter to the } \\
\text { editor (\%) }\end{array}$ & Others (\%) \\
\hline University of Toronto Medical Journal & 39 & 0 & 2.6 & 5.1 & 0 & 0 & 92.3 \\
\hline Yale Journal of Biology and Medicine & 77 & 14.3 & 26.0 & 7.8 & 0 & 0 & 51.9 \\
\hline Dalhousie Medical Journal & 21 & 0 & 9.5 & 0 & 9.5 & 0 & 81.0 \\
\hline $\begin{array}{l}\text { University of British Columbia Medical } \\
\text { Journal }\end{array}$ & 32 & 0 & 15.6 & 3.1 & 6.3 & 0 & 75.0 \\
\hline New Zealand Medical Student Journal & 56 & 0 & 0 & 0 & 19.6 & 0 & 80.4 \\
\hline McMaster University Medical Journal & 14 & 21.4 & 21.4 & 28.6 & 7.1 & 0 & 21.4 \\
\hline $\begin{array}{l}\text { Royal College of Surgeons in Ireland } \\
\text { Student Medicine Journal }\end{array}$ & 25 & 4.0 & 12.0 & 8.0 & 4.0 & 0 & 72.0 \\
\hline Australian Medical Student Journal & 10 & 20.0 & 10.0 & 0 & 0 & 0 & 70.0 \\
\hline $\begin{array}{l}\text { University College Dublin Medical } \\
\text { Student Journal }\end{array}$ & 10 & 0 & 10.0 & 0 & 0 & 0 & 90.0 \\
\hline $\begin{array}{l}\text { Journal of Asian Medical Students } \\
\text { Association }\end{array}$ & 52 & 3.8 & 5.8 & 0 & 0 & 0 & 90.4 \\
\hline Medical Student Press Journal & 7 & 14.3 & 0 & 0 & 0 & 14.3 & 71.4 \\
\hline $\begin{array}{l}\text { International Journal of Medical } \\
\text { Students }\end{array}$ & 82 & 15.9 & 8.5 & 9.8 & 4.9 & 7.3 & 53.7 \\
\hline $\begin{array}{l}\text { American Medical Student Research } \\
\text { Journal }\end{array}$ & 5 & 80.0 & 0 & 20.0 & 0 & 0 & 0 \\
\hline Turkish Medical Student Journal & 23 & 47.8 & 26.1 & 17.4 & 0 & 8.7 & 0 \\
\hline Harvard Medical Student Journal & 7 & 14.3 & 42.9 & 14.3 & 0 & 0 & 28.6 \\
\hline The McGill Journal of Medicine & 27 & 0 & 0 & 0 & 7.4 & 0 & 92.6 \\
\hline Amsterdam Medical Student Journal & 20 & 0 & 15.0 & 0 & 5.0 & 5.0 & 75.0 \\
\hline $\begin{array}{l}\text { Florida Medical Student Review } \\
\text { Journal }\end{array}$ & 14 & 7.1 & 0 & 64.3 & 14.3 & 14.3 & 0 \\
\hline British Student Doctor Journal & 40 & 5.0 & 0 & 0 & 15.0 & 5.0 & 75.0 \\
\hline Median (IQR) & $23(30)$ & $5(15.9)$ & $9.5(15.6)$ & $3.1(14.3)$ & $4(7.4)$ & $0(5)$ & $72(52.4)$ \\
\hline
\end{tabular}

\section{DISCUSSION}

Of the medical students who were involved in research and publications, $84 \%$ had intentions of continuing a research career during their lifetime, which is linked to long-term success in academia $(5,10,11)$. The publication process is vastly competitive and time-consuming in leading peer-reviewed journals. This lengthy process is often topped with heart-breaking rejection which results in up to $70 \%$ of students' works remaining unpublished $(7,12)$. Considering the declining number of physician-scientists, a supportive and encouraging environment is needed, which may be filled by student-run journals (13). MSJs are of chief value to encourage and develop aspiring researchers. MSJs play a vital role in maintaining a heightened interest in research (14). Therefore, the parameters of these journals should be thoroughly investigated. We hereby and evaluate journals run by medical students in predetermined features.

The oldest MSJ found was the University of Toronto Medical Journal in 1923. The amount of MSJs showed a subtle increase from then until 2005, and an inclination happened after that year. Among all MSJs, 7 of them were based in the United States, 5 were from Canada, 5 were published in Europe, 2 were active in the Asia-Pacific region and 1 journal was based in Australia. Since Yasir et al.s study (2) in 2016, only two new MSJ started publishing, which are Florida Medical Student Review Journal and British Student Doctor Journal. These values may indicate a higher need for more MSJs in some areas throughout the world, as they are platforms for visibility and bridges for medical students to the research field. Active and periodical publishing is a criterion that indicates the consistency of a journal, and all MSJs reviewed in this research had a pre-set amount of issues to be published annually. The MSJs evaluated in this study, published a median of 2 issues per year, at a maximum of 5 and a minimum of 1 issue. However, issues released in a year are not the sole parameter to determine a journal's activity as articles published in an issue differ from journal to journal.

Malin et al. (15) stated that researchers interacting, communicating between, and elaborating on each other's ideas were necessary to build a research community. In this manner, a median of 17.5 students took part in the editorial processing of MSJs. For example, University College Dublin Medical Student Journal was found to have the least number of students $(n=10)$ on the editorial board, whereas the highest number $(n=78)$ was in the Yale Journal of Biology and Medicine.

The number of articles published in the year 2020 displayed great variety. The median publication number was 23 , with a minimum of 5 and a maximum of 82 articles. Only $13.1 \%$ of articles published were original articles, $10.8 \%$ were review articles, and $9.4 \%$ were case reports. These values clarify that there is room for improvement in MSJs in terms of original articles, review articles, and case reports published, possibly due to the lack of proper guidance and mentorship from the relevant researchers. 
Meaningful mentorship and in-depth guidance are crucial in the academic career and progress of blooming researchers. A study by Angel-Isaza et al. (16) pointed out that physician-scientists were looked up to the most and taken as role models by $57 \%$ of their researcher population. Another study run by Bonilla-Escobar et al. (5) reported $30 \%$ of medical students engaged in research are demotivated by lack of mentorship. Of all 20 MSJs, 13 of them had an established advisory board comprising a median of 14 members. Journals that were indexed in an academic bibliographic database all had at least 10 members as their academic advisors. These data may indicate that the guidance of mentors may lead to MSJs which are higher reputed and better-known.

Being indexed in search engines is one of the most prominent challenges that MSJs face. Among all 20 journals that were included in the study, 2 were indexed in PubMed, 1 was indexed in Scopus, 1 was indexed in both Scopus and SCIE. The lack of indexing for the majority of MSJs negatively affects their visibility. Being highly selective, the terms of eligibility for indexing in such search engines often cannot be tailored to fit the needs of MSJs. This may be due to the lack of general knowledge among the scientific community about the hardships MSJs face, such as the constant changes in the editorial board line-ups due to the very nature of being students and the lack of expertise of the all-student editorial boards in relevant medical fields. Additionally, being few in numbers may have deprived MSJs of much-needed regulations about eligibility for indexing and being evaluated in a distinct category of MSJs, rather than being assessed amongst world-class scientific journals.

However, there were some limitations in our study. The journals were evaluated in a certain timeframe; therefore, the data may not present an overall look throughout the history of journals that have been discussed. The journals that do not take place on search engines (Google $\odot$, Yahoo!, and Bing) were excluded from the study. Medical student journals present on these engines and databases but lacking necessary data were also excluded from the study.

Subsequently, an increased number of undergraduate researchers and pre-trained scientists in the medical field may accelerate novel discoveries by reducing the amount of time spent grasping the principles of conducting scientific research after graduation. Although the first MSJ is nearly a century old, a substantial number of MSJs began their publishing life in the new millennium, with the pioneer being New Zealand Medical Student Journal. The increased steepness of this slope may be linked to medical students' rising awareness of the necessity of gaining experience in scientific research, and possibly the realization that once they graduate, they will be the successors of the current physician-scientists.

In conclusion, the majority of MSJs are based in North America and Europe, and a substantial amount of the published articles falls into the "others" category. Considering the lack of effective guidance and regulations with relevance to indexing, MSJs face certain challenges regarding visibility, accessibility, and publishing articles. However, provided that the editors of MSJs remain keen, motivated, and focused, MSJs will contribute to the scientific community by creating a supportive and intellectual environment for aspiring researchers where they can enhance their understanding of scientific research and publishing skills.
Ethics Committee Approval: N/A

Informed Consent: N/A

Conflict of Interest: The authors declared no conflict of interest.

Author Contributions: Concept: FEA, BK, BT, CY, EŞ, EÇ, JÖ, PT, NS. Design: FEA, BK, BT, CY, EŞ, EÇ, JÖ, PT, NS. Supervision: FEA, BK, BT, CY, EŞ, EÇ, JÖ, PT, NS. Resources: FEA, BK, BT, CY, EŞ, EÇ, JÖ, PT, NS. Materials: FEA, BK, BT, CY, EŞ, EÇ, JÖ, PT, NS. Data collection and/or processing: FEA, BK, BT, CY, EŞ, EÇ, JÖ, PT, NS. Analysis and/or Interpretation: FEA, BK, BT, CY, EŞ, EÇ, JÖ, PT, NS. Literature Search: FEA, BK, BT, CY, EŞ, EÇ, JÖ, PT, NS. Writing Manuscript: FEA, BK, BT, CY, EŞ, EÇ, JÖ, PT, NS. Critical Review: FEA, BK, BT, CY, EŞ, EÇ, JÖ, PT, NS.

Financial Disclosure: The authors declared that this study received no financial support.

Editor-in-Chief's Note: Nine of the authors of this article, Fatih Erkan Akay, Beliz Koçyiğit, Berfin Tan, Ceren Yüksel, Eylül Şenödeyici, Elif Çalışkan, Janset Özdemir, Pınar Tuncer and Necdet Süt are members of the editorial board of Turkish Medical Student Journal. However, they did not take place in any stage on the editorial decision of the manuscript. The editors who evaluated this manuscript are from other institutions.

\section{REFERENCES}

1. Al-Busaidi IS, Sharif K, Hassan A. Gender, geographic and socioeconomic representation in medical student journals: a cross-sectional analysis. Cureus 2021;13(1):e12838.

2. Alamri Y. How do medical student journals fare? A global survey of journals run by medical students. Educ Health (Abingdon) 2016;29(2):136-41.

3. Thawani R, Kaur G, Chatterjee P et al. From the editors of a student journal. Educ Health (Abingdon) 2013;26(2):115-6.

4. Al-Busaidi IS, Alamri Y. Peer review policies in medical student journals. Postgrad Med J 2018;94(1112):362-3.

5. Bonilla-Escobar FJ, Bonilla-Velez J, Tobon-Garcia D et al. Medical student researchers in Colombia and associated factors with publication: a cross-sectional study. BMC Med Educ 2017;17(1):254.

6. Chang Y, Ramnanan CJ. A review of literature on medical students and scholarly research: experiences, attitudes, and outcomes. Acad Med 2015;90(8):1162-73.

7. Al-Busaidi IS, Wells CI, Wilkinson TJ. Publication in a medical student journal predicts short- and long-term academic success: a matched-cohort study. BMC Med Educ 2019;19(1):271.

8. Navalta JW, Lyons TS. Student peer review decisions on submitted manuscripts are as stringent as faculty peer reviewers. Adv Physiol Educ 2010;34(4):170-3.

9. Ha TC, $\mathrm{Ng} \mathrm{S}$, Chen $\mathrm{C}$ et al. Inclination towards research and the pursuit of a research career among medical students: an international cohort study. BMC Med Educ 2018;18(1):86.

10. Amgad M, Man Kin Tsui M, Liptrott SJ et al. Medical student research: an integrated mixed-methods systematic review and meta-analysis. PLoS One 2015;10(6):e0127470.

11. Fang D, Meyer RE. Effect of two Howard Hughes medical institute research training programs for medical students on the likelihood of pursuing research careers. Acad Med 2003;78(12):1271-80.

12. Lin S. Student journals: facilitating medical student research and physician-scientist development. Mcgill J Med 2006;9(2):82-3

13. Milewicz DM, Lorenz RG, Dermody TS et al. Rescuing the physician scientist workforce: the time for action is now. J Clin Invest 2015;125(10):3742-7.

14. Al-Busaidi IS. Medical student journals: critical to the development of physician-scientists. Educ Health (Abingdon) 2016;29(3):273-4.

15. Malin B, Carley K. A longitudinal social network analysis of the editorial boards of medical informatics and bioinformatics journals. J Am Med Inform Assoc 2007;14(3):340-8.

16. Angel-Isaza AM, Botero-Suarez HF, Gonzalez DC et al. Interest of medical students for investigation. CIMEL 2010;15(1):9-13. 